\title{
Korea's and Vietnam's Encounter and Reaction towards Western Ideas in the Flux of Western Intervention: Focusing on Selective Factors from the Seventeenth to mid- Nineteenth Century
}

\author{
La Duy Tan ${ }^{1}$, , Le Thi Ngoc Cam ${ }^{2}$
}

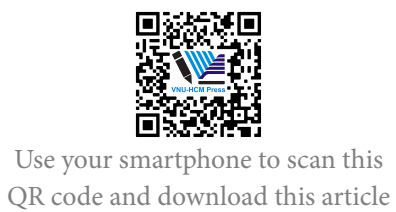

${ }^{1}$ University of Social Sciences and Humanities, VNU-HCM

${ }^{2}$ Duy Tan University, Da Nang

Correspondence

La Duy Tan, University of Socia Sciences and Humanities, VNU-HCM

Email: duytan.kr@hcmussh.edu.vn

History

- Received: 20/2/2020

- Accepted: 3/12/2020

- Published: 28/12/2020

DOI : 10.32508/stdjssh.v4i4.606

\section{Check for updates}

\section{Copyright}

(c) VNU-HCM Press. This is an openaccess article distributed under the terms of the Creative Commons Attribution 4.0 International license.

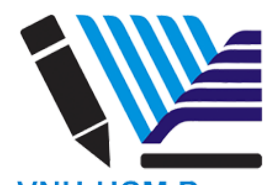

VNU-HCM Press

\begin{abstract}
This paper is a comparative research on how Vietnam and Korea struggled to accommodate and interact with Western ideas in the advent of Western intervention in the East Asian region, based on the closely related cultural and historical background between the two East Asian countries. The author specifically focuses on the rise of Western ideas, i.e. Catholicism in the two countries within the dominant impacts of Confucian Sino-centric perception adopted by Confucian scholars and rulers for centuries.

The research indicated significant resemblance in the pattern of Korea and Vietnam's reception and reaction toward the influences and challenges inflicted by the West, which was predominantly driven by the Sino-centric world view. In this light, both countries struggled through consistent social and political unrest and finally commenced to close the gates to the outside world in an attempt to protect the ruling powers. Vietnamese rulers, however, were by far less conservative and aggressive against the presence of the West in their domains due to their dependence upon Western advanced military technology, particularly during the internal conflicts between the Trinh and Nguyen factions. However, after the unification under the reign of Nguyen family, despite previous contacts with the West, Vietnam gradually become a fervent Confucian state. Meanwhile, in the same period of the Western provocation in East Asia, Korea was a full-fledged and unified kingdom under the rule of Yi family, Choson was more alerted about the rise of new ideas brought in by the West; thus, their reactions toward Western ideas were more brutal and merciless in order to protect the kingdom's correct ideology.

Conclusively, no matter how Vietnamese and Korean scholars and rulers were fascinated by Western advancement in technology, owing to their commitment to the Sino-centric worldview they were reluctant to regard Western ideas in positive ways; thus, gradually failed to adapt themselves to the road to modernization which historically contributed to the decline of the nations in the following periods.
\end{abstract}

Key words: Confucianism in Vietnam and Korea, Choson, Dai Viet, Western ideas in Vietnam and Korea, National containment policy

\section{INTRODUCTION}

\section{Literature review}

During the last decade, as Vietnamese people and scholars have become more interested in Korea due to the deepened relationship between the two as a result of various economic investments and cultural exchanges, certain number of studies and research have been conducted to examine the similarities and differences between the two nations. Among all, many schoolar argued Korean modernity and the process of Korean development the same academic trend also occurred within Vietnamese academia, though a bit later in time.

Projected by current political worldview of the central government, it is not rare to find history text- books, essays and research which were thicken with hatred and negative statements against Western intervention in Vietnam. However, after the "Doi Moi" renovation policy in Vietnam, coming along with tolerant and open-minded opinions about Western ideas and lifestyles, studies focusing on colonial modernity sparked new academic trend. For instance, Pham Hong Tung ("Presentation and Interpretation of Colonial History in Vietnamese and French Textbooks", research paper sponsored by the Academy of Korean Studies (South Korea) (2006)) suggested novel perspectives by which the French colonialism could be reconsidered on how the French influenced Vietnamese lifestyle and ideology in Vietnamese and French history textbooks. Thuy Khue $(2015)^{1}$ put huge efforts on collecting a variety of sources to of- 
fer multidimensional perspectives on the images of the French in the relations with Gia Long. Her work aimed to correct several misunderstandings and misinterpretations of previous research. However, the main trend of studies on Vietnam's encounter with the West still take biggest account on the idea of the French aggression toward Vietnam along with the involvement of Christian priests. Many of those particularly focused on the inapt leadership of Nguyen Dynasty in terms of foreign policy with the French.

Korea, on the other hand, by the sudden encroachment of Japan in late nineteenth century, becoming the colony of her neighbor country was one of the most bitter and painful experiences for her people. Perhaps, the annoyance caused by the West from late seventeenth to mid nineteenth century was well covered by the Japanese dominance at the end of Choson dynasty. Andre Schmid (2002) ${ }^{2}$ described how Korea's nationalism and Korean identity blossomed in the whirlpool of foreign countries' intervention in the last stage of Choson dynasty and the closure of its conventional ideological system. Ultimately, it was not the West that caused drastic changes to the kingdom. Therefore, Korea's encounter with Western idea was depicted by the rise of Christianity and in the picture of political chaos during the last stage of Choson dynasty where it was most likely taken as a means of political purges. This trend of research is predominant in a wide range of Korean history studies by Korean scholars.

Though there are a large number of studies arguing the involvement of Western power in East Asian region, comparative reseach on the patterns of Korea and Vietnam's interaction and reaction are not yet conducted. Thus, with this research, the author strived to seek for and offer a potential academic guideline for further comparative studies of East Asian history. However, considering the long period of time in the scope of this studies, it is not easy to cover all the historical evidences in order to avoid certain flaws due to heavy dependence on secondary sources.

\section{Thesis questions}

Korea's early encounter with Western ideas was documented after the Japanese invasion of Korea in 15921598 (known as the Imjin Waeran 任辰倭亂). Imjin Waeran did not only cause a large number of casualties and massive loss of property, but also strikingly influenced the fixed Confucian traditions and morality of the Choson dynasty(朝鮮). Prior to the Imjin Waeran, Catholic missionaries in Japan had already considered spreading the belief system to Korea.
Other foreign missionaries outside Japan also strived to introduce Catholicism to Korea but did not achieve much success $\left[{ }^{3}\right.$, p.8-9]. This was because, after the Imjin waeran, the Choson monarchy, filled with trepidation about possible future foreign incursions, deliberately nullified all the channels connecting with the outside world. Hence, it was not until the rise of the Sirhak(實學/practical learning) movement in the late seventeenth century did Choson scholars become informed about the presence of Western civilization [ ${ }^{4}$, p.5].

From the early seventeenth century, Vietnam (known as Dai Viet(大越)) was in a state of civil war caused by the two powerful lord families Trinh (鄭) and Nguyen (阮), which lasted for more than one hundred years [ ${ }^{5}$, p.297-283]. In such a situation, Alexandre De Rhodes (1591-1660) arrived in Dai Viet to start his nascent missionary among the local people [ $\left.{ }^{6}, \mathrm{p} .439-441\right]$. His ambition for evangelizing the Vietnamese people was undoubtedly favored by the decline of Confucian studies in Vietnam during the civil war. As an intellectual missionary, De Rhodes did not only understand Vietnamese local traditions but also applied Mateo Ricci's evangelizing experiences in China to Vietnam. His emulation of Ricci's approach was based on the fact that Vietnam was also highly Sinicized at that time $\left[{ }^{6}, \mathrm{p} .456\right]$.

By investigating the reception and perception of Western ideas, one can understand the propensity for further modernization process in the two countries, including their fate in relations with the West. In this paper, the author electively selected a variety of historical incidents happened during the period from the seventeenth and nineteenth centuries for the research base since this span of time undoubtedly evidenced dramatic changes in political and social affairs occurring in Korea and Vietnam, especially within the advent of Western intervention. By examining the homogeneity and differentiation of the receptive patterns of the Western ideas, the write also managed to presume possible correlations between the past and the present in order to argue the underlying forces and themes which evidently drove the relationship patterns of Vietnam and Korea with Western countries.

\section{Research methods}

This research is projected based on existing historical research and documents on Vietnamese history and on Korean history which previously managed to elucidate the process of perception and reception of Western ideas the both countries. Despite various research and sources available on each single research 
subject, there are not yet any research that comprehensively analyzes the similarities and differentials between this two research subjects. Hence, in order to answer the question theses raised throughout this paper, the writer mainly utilized two research methods as explained below.

First of all, the writer applied historical data analysis method on the aforementioned historical period. This method was commenced by selectively combining all related data and documents, followed by scanning and categorizing cross-paralleled objects. All scanned and categorized cross-paralleled objects between the two research subjects extracted from the first method were then evaluated and argued in historical comparative methods. In this methods, each selected objects should either share the similar historical background or relevance, not to violate the logical fundaments $\left[{ }^{7}\right.$, p.91- 93].

Second is the historical predictive and interpretation methods. This method is applied after the other first method, and can be seen intermingled with the first method at some parts. Owing to this method, the writer managed to draw several presumptions and explication on the theme of historical developments for thorough understandings of Vietnamese and Korean history, including historical indicative factors which relate and connect the reality of the present with the lessons drawn out from the past $\left[{ }^{3}\right.$, p.210- 211].

\section{KOREA AND VIETNAM IN THE ADVENT OF WESTERN INTERVENTION}

\section{Korea: Political and social unrest in late Choson period}

Before the Japanese invasion (1592-1598), Korea had applied Confucianism as a core ideology for over two hundred years in an attempt to create a Confucian society as an ultimate goal of nation building $\left[{ }^{8}\right.$, p.377]. Confucianism which was practiced in Korea was not the original Confucianism from China, which focused on classical texts and conveyed numerous metaphysic implications and practices. Korean Confucianism was known as Sŏngnihak (nature and principle learning) developed by Chu Hsi (11301200), then modified and adjusted to Choson political culture by prominent Choson Confucian scholars such as Ki Tae-song, Yi-hwang and Yi-il, which was articulated as a more social and political oriented system of philosophy [ ${ }^{9}$, p.151- 152]. In the late sixteenth century, suddenly struck by the Japanese invasion, Korea was shaken from its enduring illusions of the past. Facing the bitter aftermath of the invasion,
Korean aristocrats yangban(雨班) began to reconsider a variety of internal and external issues in their Confucian state. They lamented the deteriorating position of their country compared to Japan, the neighbor country which Korean people always used to look down upon in terms of its cultural foundation, i.e. Chinese civilization. Adhered to the Chinese worldview in its relations with Japan, Korea regarded itself as the main medium channel by which the Chinese cultural package was transmitted to Japan $\left[{ }^{10}\right.$, p.15- 17].

The country of Confucian literati that Choson had longed to build was unable to defend itself against the expansionist aggression of its archipelagic neighbor. After a hundred years of enjoying peace and indulging in Neo-Confucian precepts, Choson became less afraid of the threat of foreign invasion, thus neglectful of strengthening military forces. Due to the large devastation during the Imjin war and the royal family's irresponsibility, the populace explosively expressed their infuriation about the government's incompetence. At the peak of the war, people in lowborn classes, mostly slaves, rose up to destroy the registry where slave rosters were stored [ ${ }^{11}$, p.144- 145], which implied that the war worsened the conflicts underlying Choson social class inequality and discrimination. Evidently, these rebellions caused turmoil and discontinuity in social traditions. Korea's NeoConfucian state obviously failed to run political and social affairs properly, as it did more efficaciously in previous centuries [ ${ }^{12}$, p.1003-1019]. In other words, the Japanese invasion of Korea in the late sixteenth century was the "melting point" of class' conflicts which began to challenge the Choson Confucian-led social system.

Furthermore, the Confucian hierarchical social system, i.e. "scholars- farmers- artisans- merchant " (士農工商) that the rulers had built for centuries became no longer competent with social changes in the late Choson period. The literati class, during war with the Japanese, lost their fame as moral representatives among other classes. They barely cared about the miserable life of other fellow countrymen, and behaved cowardly and selfishly throughout the hard times. A number of manufacturers and merchants began to hold large amounts of property, which allowed them to engage more with political affairs; while in contrast, a lot of yangban family gradually lost their social status as a result of their insistent refusal of economic involvement. Those newly emerging manufacturer and merchant classes craved social reforms so that they could pursue more profit and rights, whose existence exposed a potential challenge to the status-quo of the society. 
In the central government, there were two opposing groups of aristocrats that fought for the succession of the king: The Southerner (namin) and the Westerner (sǒin). The former supported the tolerant policy of Gwanghae-gun (1608-1623) toward China under the reign of the Ming dynasty, while the later criticized his disloyalty toward the Ming dynasty that Choson Dynasty was indebted to for its military assistance against Japanese aggression [ ${ }^{13}$, p.305-315]. By belittling Gwanghae-gun's misrule and immorality, the Westerners (sŏin) took the power. This Westerner group was then divided into two sub-groups: Old Doctrine (noron) and Young Doctrine (soron). In the political process, the Old Doctrine gradually occupied more important positions in the court, leaving no space for the Young Doctrine. All the factions that existed in the late Choson Dynasty had initially been parts of the ruling class (yangban) was now dispersed, leaving a political predicament for the country [ $\left.{ }^{11}, \mathrm{p} .164-171\right]$.

Despite pervasive changes within the society, instead of locating proper solutions to the crises the Choson government aggravated the current situation by isolating the country from the outside world. The Japanese invasion made Choson rulers skeptical and afraid of foreign countries, including Qing China established in the mid-seventeenth century after the collapse of the Ming dynasty. In such suffocating political and social unrest, Sirhak (practical learning) movement emerged as incipient dissident studies that suggested reform proposals to the corrupt and stagnant Choson society. Sirhak scholars criticized the metaphysical interpretation of Sŏngnihak and the wrong-doings of Confucian literati. Distinctly, most of them belonged to yangban factions that lost their family's political power due to the factional strife. By precipitating Sirhak studies, these outcast yangbans aspired to regain their political status. From the perspectives of modern Korean history, Sirhak is considered historically significant since, for the first time in Korean history, Confucian scholars commenced their social reform proposal for the sake of common people, especially for the right of merchants and peasants in the society. In this sense, Sirhak is interpreted as "revised" or "reformed" NeoConfucianism that particularly urged to avoid perusing classical texts and encouraged practical understanding of social and political problems as a genuine means of Neo-Confucianism practice. Moreover, Sirhak also distinguished itself from the conventional understandings of Neo-Confucianism by its pioneering attempt to consolidate the "Korean identity", which encouraged scholars to look thoroughly into their social problems, heartened to nurture and embrace Korean culture while rebutting the sycophantic ideas of Sadae ("serving the great/ serving China") and Sohwa ("being a small China"). In order to enrich and enhance the "Korean identity", Sirhak scholars started to study new technology and ideology from the West, hinting that China was not the only source of civilization in the world. In that process, they were attracted by the superiority in technology of the West [14, p.229- 241].

Though many missionaries in Japan and from other foreign countries tried to spread Catholicism into Korea from as early as the late sixteenth and early seventeenth centuries, owing to the country's xenophobic policy and containment, not many scholars and commoners had any chance to approach Western ideology in a thoroughly open way. For instance, Vincent Kwon, who was abducted to Japan as a war slave, was evangelized by Western missionaries there and later returned to Korea in an attempt to convert his fellow countrymen. His journey home for a religious cause was no more fruitful than other foreign missionaries' [ $\left.{ }^{15}, \mathrm{p} .8-9\right]$. In reality, not until the late eighteenth century did people in the Choson dynasty have direct contact and obtain rigorous understanding of Catholicism. The major source of Western ideas for scholars in Korea was China [ ${ }^{11}$, p.172]. Before having direct relations with the West through China Sirhak scholars studied Catholicism secretly in their home country. They mainly learnt about Western ideas from one copied version of The True Doctrine of the Lord of Heaven written in Chinese text by the Jesuit missionary Matteo Ricci in the seventeenth century and which was smuggled from China [ ${ }^{16}$, p.5]. Korean people familiarized themselves with Western ideas through periodical envoy activities in China, where the envoys enjoyed more freedom to meet and talk with Western missionaries based in Peking. As a result, the first community of Western religious studies in Korea was established in 1777 when a group of young Confucian scholars started to gather to study the Jesuit tracts. Later in 1784, Yi Sŭng Hun, one member of the group, accompanied his father as one of the foreign envoys to Peking where he met Western priests. After being baptized in China, he went back to evangelize his group members $\left[{ }^{17}, \mathrm{p} .10\right]$.

Beginning in the seventeenth century, after a hundred years under the exclusive dominance of Confucianism, Choson began to face numerous problems. One major problem was the unrest between classes in the society. Class stratification could not serve the people's desires anymore, which subsequently negated the rights of the new emerging classes to freely pursue 
benefits in economic and political processes. In such a situation, for the first time in Korean history Sirhak scholars, who were deemed as progressive Confucians, reiterated their social reform proposal. They were also the forces that, for the first time, brought non- East Asian factors into their hermit kingdom.

\section{Vietnam: Trinh- Nguyen civil war and the decline of Confucianism}

Vietnam, for a thousand years under Chinese domination, had not obtained independence until the midtenth century through the victory of Ngo Quyen (吳權) on the Bach Dang (白藤江)river (938 A.D) [ ${ }^{18}$, p.267271]. After independence, Vietnam voluntarily practiced the same "privilege" as other East Asian countries, particularly Korea. Vietnam was willing to be a subordinate state to China in order to warrant its sovereignty and suzerainty. Similarly to Korea, the Vietnamese monarchy paid tribute to China on designated occasions and acquired investiture from the Chinese emperor as an approval of legitimacy in their home country [ ${ }^{19}$, p.391-392]. In other words, after attaining its own sovereignty Vietnam deliberately drove itself into the circle of the Sino-centric world. In order to reconstruct and strengthen its governmental system, hardly found any other alternative models, Vietnamese rulers projected Confucianism as a dominant ideology in political culture. Following China in the seventh century and Korea in the eighth century, Vietnam's civil service exam system was designed in the eleventh century as a firmed practice of Confucianism to initiate a Confucian political environment. This practice was aimed at creating Confucian aristocrats as a core ruling class in Vietnamese society [ ${ }^{20}$, p.20]. Similar to Korea, Vietnamese rulers devoted themselves to build the country in the concept of "being a small China” (小中華思想) while trying to maintain its own national autonomy [ ${ }^{6}$, p.26-27].

However, through the course of one hundred years of civil war, Confucianism gradually lost its charismatic values in the society. Dai Viet was ostensibly ruled by the Le(黎) royal family, but the Le family's suzerainty over the country remained only in theory. From the seventeenth century, the country was governed by the social "dualistic" political systems in which the king's power was symbolic while political decisions were determined by regional lords (chua): Trinh in the North and Nguyen in the South. Alexander Woodside has argued that this "dualistic" system was somehow identified with the divided rule between emperors and shoguns in Japan [ ${ }^{20}$, p.29]. Meanwhile, other scholars have added that the conflicts between the North and the South were so acute that the two parts of the country were torn into two independent countries [11, p.26-27]. The devaluation of Confucianism was mainly reasoned by the sale of entrance to civil examinations to wealthy members of low social classes during the 1700s, such as merchants, peddlers, meat shop owners, etc., in order to sustain the military budget for the ongoing war $\left[{ }^{20}, \mathrm{p} .19\right]$. This practice also happened in Choson as a tool of bolstering the dying economy in the post-war period. After taking control of the country from Tay Son, King Nguyen (especially King Minh Mang), in order to address the decline of Confucian values, starting in 1838 encouraged local scholars in some Northern areas to re-cultivate Han customs to fit Vietnamese culture and reorganized periodical civil service exams [ ${ }^{20}$, p.22].

Challenging Woodside's research on Confucianism in Vietnamese society, McHale questioned the ubiquity of Confucian practices during the course of Vietnam history $\left[{ }^{21}\right.$, p.66-101]. McHale contends that common Vietnamese people could only practice Confucianism on a quite superficial level, which means that they hardly had thorough understanding of Confucian classics and its philosophy. Commoners in Korea and Vietnam were certainly not as knowledgeable of Confucian classics as Confucian literati at their times, but they could share the same level of understanding Confucianism. In addition, Confucianism in Korea and Vietnam was the ideology for the social and political privileged class: yangban (兩班) and nha nho (家儒) respectively who were legitimated to rule the people and influence the entire society. For that reason, common people accounting for the majority of total population indubitably obtained a superficial understanding of Confucianism [ ${ }^{22}$, p.298]. As a consequence, their practice of Confucian values was in fact initiated under the command of the ruling class by certain laws $\left[{ }^{23}\right.$, p.24].

\section{Comparison remarks}

In comparison, owing to distinctive geographical factors, common people in Dai Viet seemed to interact with varied cultural sources, while people in Choson, due to the isolated location, mainly had direct contact with China. Hence, for most common Vietnamese people China was not the sole channel of culture they engaged with. In the course of Vietnamese history, one can observe that there was the gradual territorial expansion stretching from the North to the South. The Central region of Vietnam was once the territory of the Champa kingdom, while the South was part of the Khmer Empire that had its capital at Angkor, now 
in modern-day Cambodia. In the process of southward expansion, Vietnamese culture became enriched by being infused with local cultures in the Center and the South $\left[{ }^{4}\right.$, p.10-11]. Consequently, compared with the common people of the Korean peninsula, Vietnamese commoners had relatively less profound understanding of Confucianism. Moreover, one hundred years of war ignited by the conflicts between Trinh and Nguyen was an undeniable factor that lessened Confucian values in Vietnam more greatly than what the Japanese invasion of Korea had impacted on Choson society.

Before the widespread presence of Western people in Asia, specifically, in Sino-cultural countries, Vietnam and Korea had experienced turbulent scenarios caused by internal and external forces. In comparison to Vietnam, Korea relatively maintained more healthy relations with China and Japan for centuries which gave the royalties and elite class more favorable spaces to develop and enforce Confucius' "righteous thoughts" to the localities; meanwhile, Vietnam did not only fought with China for its independent sovereignty but also dealt with factionalism and regionalism ignited by the ruling classes. Even though the Japanese invasion war waged upon Korea evidently led to social unrest for the next decade, its influence could not bring Confucius thoughts down to a severe collapse. It was too early for a new set of ideas to be sought as a progressive solution to the society of Choson. The only window through with Korean scholars could take a glimpse with caution into the world outside their peninsula was China. On the other hand, the civil war between Trinh and Nguyen in Vietnam along with the division of ruling territory created an "open hub" in the southern part for interactions with the outside world, accepting new ideas and people of various ethnicities. These historical backgrounds of the two states led to different paths of reaction toward the rise of Western ideas in each country.

\section{KOREA AND VIETNAM'S REACTION TOWARD WESTERN IDEAS}

\section{Korea: From ruling class down to common populace}

Among the countries in the Chinese world, Japan is known to be the earliest country in the area that accepted Western ideas to strengthen and modernize the country. Francis Xavier's journey to Japan in 1549 embarked the inchoate development of Western ideas in the archipelagic country. Following the achievement of Francis Xavier, in 1601 Matteo Ricci commenced his missionary in China. As a "buffer country" in the middle of the two more powerful countries in the region, fearing further foreign aggression and interference, the Choson monarchy and Confucian literati tried to preserve their power and national traditions by isolating the kingdom, refusing to have any diplomatic relations with other foreign countries. When China and Japan had already been known to the West, Korea remained the "Hermit Kingdom". As a result, contrary to Vietnam which was not a completely closed society during the same period, few scholars and members of the ruling class in Korea acquired chances to familiarize themselves with Western ideas inside their country's barricade.

From the very beginning of Western ideas emerging in Korea, the Choson upper classes considered Catholicism as Western heterodoxy that challenged the status quo of the kingdom. Ideological collision between Catholicism and Confucianism peaked in 1785 when chesa rites (祭祀/Confucian ancestral ceremonies) were forbidden by the Catholic church and ancestral tablets were burnt within the community of followers [24, p.10-12]. Abandonment of ancestral rituals was censured by the government and Confucian literati. Neo- Confucianism during the Choson period emphasized the role of chung(忠/loyalty) and hyo(孝/filial piety) as pivotal social ethos, thus performing ancestral rituals played a significant role in the Choson dynasty to tie family and village members which strengthened the sense of community and ideas of social status. By practicing ancestral rituals, each member of the society became acquainted with the ideas of loyalty and filial piety to their ancestors, which thus ensured that they would act the same way toward the king.

After the Imjin war, the presence of Choson war slaves in Japan informed Westerners more of the existence of the kingdom on the Korean peninsula [ ${ }^{16}$, p.106]. Notwithstanding, few efforts to approach the hermit kingdom turned out to be successful. As the very first Westerners in Japan, the Dutch were believed to have learned about Korean peninsula geography and culture whose knowledge was later shared with other Western countries [ ${ }^{5}$, p.9-11]. From the seventeenth century, Choson scholars and members of the upper classes were more likely to have chances to learn Western ideas by reading smuggled documents from China. Subsequently, from late the eighteenth century, Choson scholars commenced to have closer contact with Western missionaries in China. Western missionaries in Peking were quickly attracted by 
Choson envoys' periodical visits to China since they realized at that time that there would be no other opportunities to become conversant with Korea in order to spread their religion to the country. Therefore, churches in Peking always warmly welcomed and were relatively more generous toward Choson envoys. Even for Choson envoys travelling to China, visiting churches in Peking gradually became a part of their diplomatic schedule each time, since they were curious about the West and particularly fascinated by Western advancement in science and technology [ ${ }^{5}$, p.12-14].

Despite the fact that missionaries in Catholic churches in China put impassioned efforts to introduce Western culture and ideology to the envoys, these Choson guests were always reluctant to regard Western ideas positively; some even expressed their negativity toward exotic Western ideas due to their strong commitment to Confucian ethos. In the eighteenth century, there were two informative journals about Western culture written by Choson envoys to China, such as Lee Gi-ji's Iram Yeon Gi and Hong Dae-young's Eulbyeong Yeonhaengnok [ $\left.{ }^{22}, \mathrm{p} .45-62\right]$ [ $\left.{ }^{24}, \mathrm{p} .11-31\right]$. Drawing from the two journals, it can be concluded that Choson scholars became captivated by Western advancement in science and technology. In their writings, Lee Gi Ji and Hong Dae-young manifested their dualistic interpretation of Western civilization. Like many other scholars, they did not conceal their admiration for Western sciences and instruments by meticulously describing Western achievements in astronomy, calendar system and artistic paintings. They believed that Western sciences and instruments were far more precise and sophisticated than the Eastern ones. On the other hand, contrary to Western missionaries' expectations, Choson envoys considered Catholicism as a heretical ideology that Western people borrowed from Eastern philosophy. Lee Sang- bong, one Choson envoy who travelled to Peking in 1760, revealed the most fundamental contradictions between Eastern and Western philosophy: "The Lord of Heaven is the so-called creator and is similar to a spirit in Confucianism. Westerners don't respect Confucianism, Buddhism, and Taoism but respect only the Lord of Heaven, thanking Him for breathing even a breath. Therefore, they respect Lord as an emperor and love and depend on the Lord as parents" (Lee Sang-bongBukwonnok) [ ${ }^{25}$, p.26]. Thus, to Choson Confucian literati, the fact that Catholicism worshipped the Lord of Heaven holier than any other worldly emperors and followers' parents was deemed as an unacceptable idea that brutally violated rudimentary Confucian ethics emphasizing filial piety and loyalty. Rather than that, in political aspects Catholicism was equated with pernicious ideas, since it incited people to seek for social equality, which was totally contrast to Choson's social stratification and its status-quo.

Starting from the late eighteenth century, though Choson scholars had the opportunity to learn about Western ideas, a lot of them failed to deviate their perception from the Sino-centric perception in which they were brought up and educated. However, the shadow of Confucianism did not hinder them from appreciating Western advancements in science and technology. This kind of mindset was systematized into tongdo soggi (東道西器) theory as one important sect of Sirhak studies in the late Choson dynasty in which progressive Confucian scholars believed that they could build a thriving country on the harmonious combination of Eastern culture and Western technology [ ${ }^{26}$, p.26].

\section{Vietnam: From tolerance to persecution}

In Vietnam, the war between Trinh and Nguyen impoverished and immiserated people, which presumably left spatial room for Vietnamese commoners during that arduous time to acquaint with Catholicism as a way to conciliate their sufferings emotionally. The accommodation of Catholicism happened quite smoothly, since commoners who spent their life during a turbulent period of the country must obtain shallow understanding of Confucian studies. Conspicuously, there was no influential ideological barrier that could restrain them from accepting new ideas. As stated by McHale in his research, only few Vietnamese commoners at that time were able to understand enough basic Chinese characters for everyday usage and not many of those were sufficiently adept at reading sophisticated characters in Confucian classics.

In the central government, occupied with the ongoing war rulers in North and South Vietnam were not fully cautious about the presence of Western missionaries who were attempting to cultivate the belief in the suffering people. Noticeably, Trinh and Nguyen even warmly welcomed Western merchants, specifically Netherlanders and Portuguese to enter Hoi An port city in the hope that they could receive Western arms or any other type of supports for their war affairs. Unlike the Netherlanders and Portuguese who set their feet on Vietnamese soil for commercial purposes, the French were to a greater extent keener on religious activities [ ${ }^{27}$, p.266-269].

In such situation, following two successful predecessors i.e. Francis Xavier in Japan and Matteo Ricci 
in China, De Rhodes, who was born in the Papal territory of Avignon, France where his ancestor migrated from Spain, was said to have originally intended to settle in Japan before he arrived in Cochin China (South Vietnam) in 1624 [ ${ }^{28}$, p.441442]. Cochin China was the new territory reformed by Lord Nguyen's family where the infiltration of different ethnicities and cultures substantially enriched the local culture as a whole. After the collapse of the Ming Dynasty in China in the seventeenth century Cochin China, which used to be part of the Khmer Empire, welcomed a mass exodus of refugees from China, who are still known as Minh Huong (明香)in the Vietnamese language $\left[{ }^{24}\right.$, p.9]. As a result, Cochin China from that time became a more favorable land for new people, cultures, and ideologies to settle in [13, p.32-34].

Inferring from Matteo Ricci's experiences of evangelization in China, De Rhodes understood that Catholicism could not have been transmitted to people if it had not conveyed knowledge and philosophy. Therefore, on his arrival in Cochin China, he enticed local viceroy with his knowledge of science by gifting the viceroy European watches and glasses. The watch worked more precisely than any methods that the localities could apply to measure time. Impressed by Western advancement in technology, the local viceroy became tolerant and welcomed his missionary work in the early seventeenth century [ ${ }^{9}$, p.444]. Furthermore, he successfully gained trust in the localities by his profundity of local traditions and his proficiency in the Vietnamese language. Compared to Confucian literati in Vietnam, he definitely kept closer contact with the commoners. By immersing himself in local culture and language in order to propagate Western ideas, he greatly contributed to the invention of the first writing system for the Vietnamese language i.e Quoc ngu based on Roman letters as an effective means of preaching, which is positively regarded as his most significant achievement by Vietnamese historians. During his sojourn in Vietnam, De Rhodes wrote two books in Quoc ngu, Latin and Portuguese known as Relazione de filici successi della fede nel regno di Tunchino (1650) and the Dictionarium annamiticum, lusitanum et latinum (1651) [ ${ }^{27}$, p.192- 193]. His efforts at understanding local culture and the language seemingly created a welcoming aura for local Vietnamese who were trying to find alternative ideology to mitigate their hardship. While Confucian education was more for the privileged, Catholicism won over the populace by its universality and egalitarianism.
Throughout the protracted wartime between the two lord families, in sympathy with the irreconcilable sufferings of the commoners, the Tay Son group consisting of three prominent peasant leaders who rebelled to wreck the power of Lord Nguyen in the South, and then advanced northward to eliminate the Trinh-Le ally. Tay Son Dynasty by Quang Trung eventually took the power and ruled the country from 1770 to 1802 , which put an end to Trinh-Nguyen's civil war period. However, taking advantage of Tay Son's neglectful control in the Southern territory, descendants and followers of Lord Nguyen's family escaped, trying to retrieve the Nguyen family's power. Claiming himself as the only living legitimate descendant of the Nguyen family, Nguyen Phuc Anh (17621820) (commonly known as Nguyen Anh) became the leader of the remnant Nguyen lord factions. He was said to have had amicable relations with the French Catholic missionary in the South, Pigneau de Behaine (1741-1799). With the support of the Jesuit missionary, he managed to call for French military aid to suppress the Tay Son rebellion [ ${ }^{29}$, p.246- 247].

After defeating Tay Son brothers, Nguyen Anh succeeded in regaining the suzerainty in $1802\left[{ }^{13}\right.$, p.38]. In the beginning of his reign period, King Nguyen (Gia Long) was relatively tolerant toward Western missionaries and the Catholics as a way to maintain amiable relations with the West, particularly with the French for helping him to regain power. After the death of Nguyen Anh, in order to stabilize central power the second king Nguyen insisted on revising Confucianism as a core political ideology. The de facto allied relations between France and Vietnam became hostile since Nguyen attempted to promote ideas of a unified country, homogeneous people to conciliate regional distrusts existing among people from the North (Tonkin) and the South (Cochin China). Hence along with increasing aggression from the French toward Vietnam, the teachings of Catholicism threatened the legitimacy of Nguyen royalties which was built on Confucian political ideology.

Similar to Korea, Confucian practices played an important role in ensuring people to pay great tribute to ancestral rituals, which remind people of the ideas of trung (loyalty) and hieu (filial piety) as basic lessons in Confucianism to strengthen communal sense and visualize social moral codes. However, King Nguyen's efforts were constantly challenged by Western ideas [ ${ }^{4}$, p.67- 75]. Confucian scholars in Vietnam commenced to belittle Catholicism as Western heresy, especially when the churches tried to segregate their followers from the non-converted community [ ${ }^{30}$, p.663]. Repeating what had happened 
in Korea, the clash between the government and Catholic community peaked when the government persecuted Catholics for abandoning ancestral rituals and burning ancestral tablets. In order to protect the believers, missionaries in Vietnam tried to seek the French intervention. Losing trust in Vietnam and blaming King Nguyen for being ungrateful, France, accompanied by her ally-Spain, attacked Vietnam for the first time in 1858. Sharing the Sino- centric world view with Korean rulers, the Vietnamese royal government decided to close the country from Western countries, forbade missionaries and persecuted Catholic believers as ways to counteract Western intrusion. During the friction between the Nguyen government and the Catholics, some Catholics were rumored to be collaborators with the French. The Catholics gradually became notorious for being disloyal factions of the country. This biased generalization even became concrete on the grounds that, after taking control of Vietnam, the French colonial government seemed to be tolerant and supportive of the Catholics, which subsequently turned Cochin China into the land of Catholicism [ ${ }^{30}$, p.665]. In Korea, during the colonial period (1910-1945) the Japanese government oppressed Catholicism in an attempt to assimilate the Korean people within the Japanese religion Shinto (神道). As a result, the Catholic community in Korea gradually gained a high reputation due to their relentless resistance against the Japanese, which is the reason why Catholicism could arguably develop into a crucial factor of nationalism during colonial period.

\section{Comparison remarks}

When the influence of Western powers and ideas became immense and prevalent, the ruling classes in Vietnam and Korea started to fear the same threats to the root of their political powers. Korea decided to stay passive in the process of observing and accepting Western ideas. Korean rulers and scholars apparently tried to seek alternative ideas which, in some respects, were referred to Western ideas in terms of Western advanced technology. Vietnam, on the other hand, did not have enough time and environment to examine and speculate how Western ideas could modify their societal aspects. People in powers of Vietnam at that time was too occupied with their efforts and ambitions of winning and regaining their power rather than focused on developing any ideas to control their populace. Ultimately, after facing with several chaos brought by the new ideas, ruling classes in both countries failed to adopt Western ideas, yet empowered Confucianism to retrieve and strengthen their legitimacy.

It is most evident that Nguyen Anh - the founder of Vietnam's last dynasty, even though was not the first royalty to have contact with Western people, was harshly blamed for filthily cooperating with the French to uproot Tay Son dynasty whose legitimacy was backed by the victorious war against China's Qing. Thus, despite his relentless effort to strengthen and solidify his newly established state, Nguyen Anh's path to enthronement was otherwise controversial. The hostile environment against his rule apparently affected Nguyen Dynasty's foreign policy toward the West in different types of negativity and alienation, which also exposed great implying threats on the foreign policy of his successors.

Choson, on the other hand, followed a different road of reaction toward Western ideas. Submerging in the factional conflicts, Vietnamese rulers from Northern and Southern Vietnam did not have any space to fully concern about the rise of Western ideas in their domain, yet tried to take advantage of Western advancement in weaponry technology, which left a relatively broad line for Western missionaries to approach the Vietnamese commoners. Choson, at the same time, regardless of several social unrests and foreign aggression, was already a full-fledged unified kingdom for hundred years; hence, the route of evangelization in Korea showed little similarity with Vietnam. In Choson, the literati and declining noblemen (chanban), not the commoners, played important role to bring up Western ideas into their peninsula through the contact with China. The negativity and hatred that Choson and Vietnam's rulers ferociously imposed upon Catholicism was that its teaching encouraged the oppressed commoners to seek for an egalitarian world which directly contrasted and degraded Confucius teachings on social orders built on filial piety.

Another noticeable differentiation of Choson can be revealed through Grand Prince Daewongun's national containment policy in the mid-late nineteenth century as a means to hinder and eradicate paradoxical ideology. Unlike king Tu Duc, Daewongun managed to expel the French and American enroachment to the peninsula in 1866 and 1871, respectively. Due to these successful defenses against the Western intrusion, along with the rising influence of his conservative supporters, Daewongun became overconfident about his containment policy which was subsequently accelerated by atrocious purges against the Korean Catholic followers and missionaries during his reign. 
Especially, Daewongun succeeded to instigate xenophobia against the West among the populace after his father's tomb was found to have been digged out in the same year of the French expedition. This deed was an absolutely unacceptable challenge against Confucian values [ ${ }^{31}$, p.294- 295]. Tu Duc and his government, on the contrary, inheriting his predecessors' foreign policy footprints, did not maintain an amicable relations with the French; instead, he and his political followers were bullied and forced to yield from time to time. Upon the request of the French, Tu Duc's tolerance toward Vietnamese Catholic believers made the last hit to the collapse of his political base across the country where conservative literati and provincial officials played significant roles in the political process [ ${ }^{29}$, p.283-287]. Hence, his efforts to retrieve the occupied lands by the French failed to lure supports from his people.

\section{CONCLUSION}

In the period from the seventeenth to nineteenth century, Vietnam and Korea encountered dramatic changes caused by internal and external turbulence. In such situation, Western ideas commenced to approach local people. Vietnam was not completely a hermit kingdom, thus paved a broader way for Western ideas to be transmitted into common populace. In Korea, due to the disastrous war with Japan in the late sixteenth century and later tensions with the newly established Qing dynasty in the midseventeenth century, the country's containment policy impeded Western ideas from flowing as evenly as it did in Vietnam. On that account, while Vietnamese commoners directly interacted with Western missionaries thanks to the local rulers' tolerance, common people in Korea were more likely precluded from Western ideas. Throughout the tumultuous period, Confucianism had already lost its charismatic values and became unfamiliar with common people, thus the rise of Catholicism as a new universal ideology exhibited a drastic challenge to Confucianism that Choson Korea and Nguyen Vietnam tried to project as a means of legitimacy for their governance. In general, the reaction toward Western ideas by the ruling classes in Vietnam and Korea was quite similar, which largely reflected the dichotomy in their policies toward the presence of Western countries. No matter how Vietnamese and Korean scholars were fascinated by Western advancements in technology, owing to their commitment to the Sino-centric worldview they were reluctant to regard Western ideas in positive ways. When ideological confrontation escalated, fearing the loss of their autonomous power to the West, Vietnam and Korea purposefully resolved to shun their connection with the outside world while trying to oppress the Catholic community. These reactions subsequently intensified the underlying conflicts between Eastern and Western culture, which rigorously provoked Western countries to undertake military interference. In that process, Vietnam and Korea were ultimately denied the chance to benefit from the West for their countries' modernization, as what had been attested in Japan.

Sharing Confucian values in the governmental structures and the culture of political process, Vietnam and Korea did not simply react toward Western ideas in the same patterns by accident. There were certain local implications and factors in each country that affected how the two country proceeded to modernization. By making comparison and elucidating several characteristics mentioned in this paper, it can be concluded that a stable and wealthy nation is not easily made from a concentrated leadership by one single person or a group of men; but a compilation of solidarity and mutual trust among all factions of the society. As more historical interpretations were argued from the similarities of Vietnamese and Korean history, Vietnamese political leaders and policy makers can take Korea into keener considerations in the current era of globalization. It is essential for a country to learn potential lessons from the others in the process of national administration, yet it is also not less important to decipher local indicators to tacitly adapt to current political situation of that nation.

\section{CONFLICTS OF INTEREST}

The authors declare no conflicts of interest upon the publication of the research

\section{AUTHORS' CONTRIBUTION}

The two authors, La, Duy Tan and Le, Thi Ngoc Cam have been working together on the completion of the article.

In the initial phase of forming and framing the structure of the article, La, Duy Tan raised the core ideas for the paper; thus, voluntarily proceeded to collect related data and research. Those ideas and reviews on previous research were, then, discussed and argued with Le, Thi Ngoc Cam via video call for several times. The conclusion on how to conduct the research on which the interpretation of the core ideas should reason was made. The two author finally agreed on the portions of task share within each other throughout the process of writing.

Specifically, the article consists of 5 main parts. Among those, La, Duy Tan were in charge of part 1 
"Introduction", part 2 "Korea and Vietnam in the advent of Western Intervention", part 4 "Conclusion" and the last part "Bibliography" while Le, Thi Ngoc Cam, on the other hand, took the whole responsibility for illustrating the most significant part of this research paper- part 3 "Korea and Vietnam's reaction toward Western ideas". Even though La, Duy Tan seemed to be the major coordinator of the paper, throughout the process of writing Le, Thi Ngoc Cam, with her invaluable experiences and sharp skills of critical thinking, evidently contributed to the review, edition and correction on all parts of our work. In addition, to ensure the most refined quality of the article, La, Duy Tan and Le, Thi Ngoc Cam successfully maintained spontaneous communication via discussion and comments on each other part of task as a means of double-checking and reviewing during the progress of writing.

\section{REFERENCES}

1. Khue T. Gia Long va Nguoi Phap: Su anh huong cua nguoi Phap trong giai doan trieu Nguyen (Gia Long and the French: A Survey on the Influences of the French in Nguyen Dynasty). Ha Noi: Hong Duc Publishing House. 2015;.

2. Schmid A. Korea Between Empire 1895- 1919. New York: Columbia University Press. 2002;

3. Elder JW. Comparative cross-national methodology. Annual Review of Sociology. 1976;2(1976):210-211. Available from: https://doi.org/10.1146/annurev.so.02.080176.001233.

4. Clark DN. Christianity in Modern Korea, The Asia Society, Lanham, Maryland. USA: University Press of America. 1986;.

5. Schrader S. Looking East: Rubens's Encounter with Asia, California. USA: The J. Paul Getty Museum. 2013;

6. Motoo F. Pet'ŭnamŭi Segyesa: Chunghwasegyeesŏ Tongnamasia Segyero (Vietnam in the Context of World History: From Chinese world to Southeast Asia), translated by Pak Hong Yŏng. Chungbuk, South Korea: Institute of Humanities, Chungbuk National University. 2009;.

7. Mahoney J. Comparative - historical methodology. Annual Review of Sociology. 2004;30:91-93. Available from: https: //doi.org/10.1146/annurev.soc.30.012703.110507.

8. Deuchler M. The Rise of Neo-Confucianism in Korea. Cambridge, MA: Harvard University Press. 1992;.

9. Eckert CL, Lee KB, et al. Korea Old and New: A History. Cambridge, MA: Harvard University Press. 1990;.

10. Key-Hiuk K. The Last Phase of the East Asian World Order: Korea, Japan, and the Chinese Empire, 1860- 1882. California, USA: University of California Press. 1980;.

11. Uk CB. Ch'oebyŏnguk Kyosuwa Hamkke Ingnŭn Pet'ŭnam Kŭnhyŏndaesa (Reading Vietnam's Modern History with Professor Ch'oe Byŏng Uk), Seoul. South Korea: Changbi Publising house. 2008;.

12. Palais JB. Confucian State Craft and Korean Institutions: Yu Hyongwon and the Late Choson Dynasty, Seattle. USA: University of Washington Press. 1996;.
13. Han MG. Imjinwaeran'gwa Hanjunggwan'gye (Japanese Invasion of Korea and Sino- Korean relations). Seoul, South Korea: Yuksa Bipyongsa Publishing House. 1999;.

14. Woo HY. A Review of Korean History vol.2 Joseon Era, translated by Halm Chaibong, Seoul, South Korea : Kyongsaewon Publishing House. 2003;.

15. Grayson JH. Christianity in Korea, Honolulu, Hawai, USA: University of Hawaii's Press. 2006;

16. Han MG. Imjinwaeran'gwa Hanilgwan'gye (Japanese Invasion of Korea and Korean- Japanese relations), Seoul, South Korea: Gyeongin Munhwa-sa Publishing house. 2005;.

17. Busswell RE, Lee TS. Christianity in Korea, Honolulu, Hawaii, USA: University Press of Hawaii. 2006;.

18. Taylor KW. The Birth of Vietnam, California, USA: University of California Press. 1983;

19. Hara T. Korea, China, and Western Barbarians: Diplomacy in Early Nineteenth Century Korea. Modern Asian Studies Cambridge, England: Cambridge University Press. 1998;32(2):389-430. Available from: https://doi.org/10.1017/ S0026749X9800273X.

20. Woodside A. Lost Modernity, Cambridge, MA: Harvard University Press. 2006;

21. McHale SF. Print and Power: Confucianism, Communism, and Buddhism in the Making of Modern Vietnam, Honolulu, Hawaii, USA: University of Hawaii Press. 2004;.

22. Dae LH. Hong Dae Yong's Beijing Travels and His Changing Perception of the West- Focusing on Eulbyeong yeonhaengnok and Uisan mundap. The Review of Korean Studies. 2006;9(4):45-62.

23. Vella WF, Thanh HN. Aspects of Vietnamese History, Honolulu, Hawaii, USA: The University Press of Hawaii. 1973;.

24. Cheol SI. The Experience of Visiting Catholic Churches in Beijing and the Recognition of Western Learning Reflected in the Journals of Travel to Beijing. The Review of Korean Studies. 2006;9(5):11-31.

25. Nam SJ. Pet'ŭnamŭi Yŏksa (Vietnam's history), Pusan, South Korea: Pusan University Press. 2000;.

26. Hwan ND. Tongdosŏgiron Hyŏngsŏng Kwajŏng Yŏngu: 18- 19segi Chosŏn Chisigindŭrŭn Sŏyangŭi Tojŏne ŏttŏk'e Taeŭhaennŭn'ga? (Research on Tongdosŏgi Theory: How Did Korean intelligentsias in eighteenth and nineteenth centuries respond to Challenges from the West?), Seoul, South Korea: Iljisa Publishing House . 2005;

27. Sŏn YI. Saero Ssŭn Pet'ŭnamŭi Yŏksa (A New History of Vietnam), Seoul, South Korea: Yeesan Publishing Co. 2002;

28. Maggs BW. Science, Mathematics, and Reason: The Missionary Method of the Jesuit Alexandre De Rhodes in Seventh Century Vietnam. The Catholic History Review. 2000;86(3):439-458. Available from: https://doi.org/10.1353/ cat.2000.0028.

29. Tsuboi Y. Nuoc Dai Nam doi dien voi Phap va Trung Hoa (Dai Nam at the crossline between France and China)(translated by Nguyen Dinh Dau). Ho Chi Minh city: Ban Khoa hoc Xa Hoi Thanh uy TP. HCM. 1990;.

30. McLeod MW. Nationalism and Regionalism: Phan Boi Chau and the Catholic Questions. The International History Review. 1992;14(14):661-680. Available from: https://doi.org/10.1080/ 07075332.1992 .9640628$.

31. Lich NV, Lan LTT. Lich su Korea: Đe tai nghien cuu cap bo (Korean History: Research Project sponsored by Vietnam Ministry of Education). Ho Chi Minh city: University of Social Sciences and Humanities VNU HCMC. 2008;. 


\title{
Quá trình gặp gỡ và đương đầu của Việt Nam- Hàn Quốc đối với các tư tưởng phương Tây trong làn sóng can thiệp của Phương Tây: Phân tích các yếu tố chọn lọc từ thế kỉ XVII đến giữa thế kỉ XIX
}

\author{
La Duy Tân ${ }^{1, *}$, Lê Thị Ngọc Cầm²
}

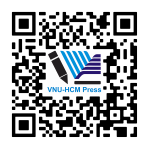

Use your smartphone to scan this QR code and download this article

${ }^{1}$ Trường Đại học Khoa học Xã hội và Nhân văn, ĐHQG-HCM

${ }^{2}$ Trường Đai học Duy Tân, Đà Nẵng

Liên hệ

La Duy Tân, Trường Đại học Khoa học Xã hội và Nhân văn, ĐHQG-HCM

Email: duytan.kr@hcmussh.eduvn

Lịch sử

- Ngày nhâan: 20/02/2020

- Ngày chấp nhận: 3/12/2020

- Ngày đăng: 28/12/2020

DOI : 10.32508/stdjssh.v4i4.606

\section{Check for updates}

\section{Bản quyền}

๑) ĐHQG Tp.HCM. Đây là bài báo công bố mở được phát hành theo các điều khoản của the Creative Commons Attribution 4.0 International license.

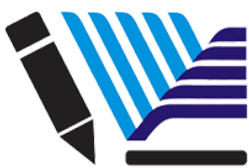

VNU-HCM Press

\section{TÓM TẮT}

Tham luận này là nghiên cứu so sánh về quá trình Việt Nam và Hàn Quốc tiếp nhận, phản ứng với tư tưởng mới của các nước phương Tây tại khu vực Đông Á, dựa trên mối tương quan vể bối cảnh văn hoá và lịch sử của hai quốc gia thuộc khu vực văn minh Đông Á này. Tác giả tập trung phân tích sự trỗi dậy của các tư tưởng phương Tây, cụ thể là Công giáo, trong bối cảnh mà giới tri thức và giới cầm quyền hai nước Việt- Hàn đã quá quen thuộc với hê tư tưởng Khổng giáo, xem Trung Quốc là trung tâm của văn minh. Nghiên cứu chỉ ra hình thái tương quan trọng yếu trong cách nhìn nhận và tiếp nhận các thách thức và tầm ảnh hưởng của các tư tưởng phương Tây trong thế giới quan Trung Hoa của Việt Nam và Hàn Quốc. Trong hoàn cảnh đó, cả hai quốc gia phải đối phó với các biến động xã hội và chính trị không ngừng dẫn đến trạng thái đóng cửa với thế giới bên ngoài nhằm bảo vê quyền lợi của giới cầm quyên. Viẹt Nam, tuy thế, lại ít bảo thủ và chống đối lai sự xuất hiện của phương Tây trong lãnh thổ của mình do sự dựa dấm của giới cầm quyền vào kĩ thuật quân sự tiên tiến của phương Tây, hiện tượng này được thấy rõ trong giai đoạn Trịnh- Nguyễn phân tranh. Trong cùng thời điểm phải đới đẩu với các thế lực phương Tây, Hàn Quốc đã là một quốc gia trưởng thành và thống nhất dưới sự thống trị của dòng họ Lee; triều Choson đề cao cảnh giác với các tư tưởng mới mà phương Tây mang đến lãnh thổ của mình. Do đó, các phản ứng của họ có phần tàn bạo hơn trong nỗ lực bảo vệ hệ thống tư tưởng chính thống của vương quốc. Nhìn chung, bài nghiên cứu cho thấy dù kinh ngạc với sự vượt trội hơn của phương Tây về mặt kĩ thuật, giới tri thức và cầm quyền ở hai quốc gia đều không tránh khỏi sự bó hẹ trong thế giới quan Trung Hoa để nhìn nhận phương Tây một các tích cực hơn; do đó, hạn chế khả năng thích ứng trong tiến trình đi tới hiện đại, và đây chính là yếu tố dẫn tới sự suy yếu của hai quốc gia này trong các giai đoạn lịch sử tiếp sau đó.

Từ khoá: Nho giáo ở Việt Nam và Hàn Quốc, Choson, Đại Việt, Tư tưởng phương Tây ở Việt Nam và Hàn Quốc, Chính sách bế quan toả cảng
Trích dẫn bài báo này: Tân $L \mathrm{D}$, Cầm $L \mathrm{~T}$ N. Quá trình gặp gỡ và đương đầu của Việt Nam- Hàn Quốc đối với các tư tưởng phương Tây trong làn sóng can thiệp của Phương Tây: Phân tích các yếu tố chọn lọc từ thế kỉ XVII đến giữa thế kỉ XIX. Sci. Tech. Dev. J. - Soc. Sci. Hum.; 4(4):677-688. 